\title{
MENEGUHKAN ISLAM NUSANTARA: Nahdlatul Ulama dan Falsafah Pendidikan Pesantren Musthafawiyah
}

\author{
Salamuddin \\ Universitas Islam Negeri Sumatera Utara Medan \\ Jl. Willem Iskandar Pasar V Medan Estate, Medan, Sumatera Utara, 20371 \\ e-mail: salamdin@gmail.com
}

\begin{abstract}
Reaffirming Nusantara Islam: Nahdlatul Ulama and the Educational Philosophy of Pesantren Musthafawiyah. This study analyzes the educational philosophy of Pesantren Musthafawiyah, a theme that has not been properly studies by former researchers. This pesantren is affiliated with Nahdlatul Ulama; as a matter of fact, its founder, Sheikh Mustafa Husein, is also the founder of NU in North Sumatra. This study data was obtained through document reviews and strengthened with prolonged observation activities, then analyzed using the Miles and Huberman data analysis models. This study concludes that as with other NU pesantrens, Musthafawiyah develops the principles of al-muhâfazhah 'ala qadîm al-shâlih wa al-akhzu bi al-jadîd al-ashlâh, tawâzun, ta'âdul, and tasâmuh, the principles of which have become the basic values that are applied in teaching and learning process. Of course, this study reinforces the conclusions of a number of researchers that Islamic boarding schools uphold a moderate understanding of Islam and reject radicalism in religion and state.
\end{abstract}

Keywords: NU, Musthafawiyah, Sunni, moderate, radical, Islamic boarding schools, Mandailing, Tapanuli 


\section{Pendahuluan}

Studi tentang pesantren memang telah melimpah ruah. Peneliti dari dalam dan luar negeri telah menghasilkan kerja akademik mereka untuk menelaah pesantren di Indonesia. Kajian mereka dimulai dari persoalan pesantren sebagai sebuah lembaga pendidikan Islam tertua di Nusantara sampai pada kaitan antara pesantren dengan radikalisme ${ }^{1}$ dan gender. ${ }^{2}$ Hanya, sejauh ini, kajian tentang falsafah pendidikan yang dikembangkan oleh pesantren belum mendapat perhatian serius dari peneliti pendidikan Islam, terutama pengkaji dunia pesantren.

Pesantren merupakan lembaga pendidikan tertua di Indonesia. ${ }^{3}$ Pesantren awalnya dikembangkan oleh kiai-kiai di pulau Jawa dan berafiliasi dengan Nahdlatul Ulama (NU). ${ }^{4}$ Memang, ulama dan tokoh Muslim selain NU dan di luar Jawa, lebih mengembangkan sistem madrasah. Ormas selain NU, seperti Muhammadiyah, Al Washliyah, dan Al-Ittihadiyah, lebih fokus mengembangkan sistem madrasah. Di antara ulama NU yang mengembangkan pesantren adalah KH. Hasyim Asy'ari. Ia merupakan pendiri NU dan pesantrennya menjadi contoh bagi kiai lainnya dalam mengembangkan sistem pesantren. ${ }^{5}$

Di luar Jawa, pesantren didirikan oleh ulama-ulama yang tidak kalah gemilang dari aspek keilmuan dan kharismatikanya. Di Sumatera Utara, Syekh Musthafa Husein merupakan satu di antara banyak figur yang ikut mengembangkan sistem pesantren. Ia mendirikan Pesantren Musthafawiyah, dan pesantren ini telah memunculkan figur penting dalam tradisi intelektual di Sumatera Utara. ${ }^{6}$ Studi tentang Pesantren Musthafawiyah memang telah dilakukan sejumlah peneliti, tetapi kajian tentang filsafat pendidikan yang dikembangkan oleh pesantren ini masih diabaikan. Studi ini penting dilakukan mengingat pesantren ini merupakan salah satu pesantren tertua di Sumatera Utara, dan telah melahirkan jaringan keilmuan yang unik di Nusantara. Afiliasi pesantren 
ini secara kultural dengan NU ikut menambah daya tarik tersendiri mengingat pendirinya, Syekh Musthafa Husein adalah pendiri NU di Keresidenan Tapanuli yang kini menjadi bagian dari Propinsi Sumatera Utara.

Studi ini merupakan hasil penelitian kualitatif non-interaktif dimana data diperoleh dari kegiatan studi dokumen yang dilengkapi dengan teknik observasi. Secara khusus, studi ini akan menguak falsafah pendidikan yang dikembangkan di Pesantren Musthafawiyah yang merupakan salah satu pesantren yang secara kultural berafiliasi dengan Nahdlatul Ulama (NU) di Mandailing Natal, Sumatera Utara. Sebelum menjawab fokus masalah, akan diulas secara sepintas tentang sejarah dan falsafah pendidikan NU. Sebagaimana telah disebut, data kajian ini diperoleh dari telaah dokumen. Data yang diperoleh dari kegiatan studi dokumen akan dibandingkan dengan kegiatan observasi, dimana akan diamati secara seksama aktivitas pesantren. Data yang diperoleh akan dianalisis dengan model analisis data Miles dan Huberman.

\section{Mengenal Nahdlatul Ulama}

Kelahiran NU pada tahun 1926 tidak bisa dilepaskan dengan perkembangan gerakan dan organisasi Islam berhaluan purifikasi (pembaharuan) ajaran Islam, seperti organisasi Muhammadiyah di Yogyakarta besutan KH. Ahmad Dahlan pada tahun 1912. Di sisi lain, gerakan Wahabi di Saudi Arabia dipandang telah mengancam keberadaan praktik keberagamaan Sunni Indonesia yang adaptif terhadap budaya lokal, dan toleran terhadap perbedaan mazhab dan keyakinan teologi. Puncak penentangan para kiai Indonesia yang berbasis pesantren terjadi ketika Raja Ibn Sa'ud ingin menjadikan mazhab Wahabi sebagai mazhab satu-satunya di Makkah, serta ingin menghancurkan seluruh warisan sejarah Islam 
maupun pra-Islam, yang selama beberapa lama diziarahi dan menilai bahwa tradisi ziarah tersebut merupakan perbuatan bidah. ${ }^{7}$

Ajaran kaum Wahabi ini tentu saja meraih respons positif dari kaum modernis di Indonesia. Di antara yang merespons secara positif adalah Muhammadiyah di bawah pimpinan Ahmad Dahlan dan Persatuan Syarikat Islam Indonesia (PSII) di bawah pimpinan H.O.S. Tjokroaminoto. Sebaliknya, para kiai pesantren yang selama ini mendukung pluralitas mazhab menolak sikap pembatasan bermazhab, dan mengecam penghancuran warisan peradaban Islam klasik. ${ }^{8}$

Karena memiliki sikap yang bertolak belakang, pihak pesantren dikeluarkan dari anggota Kongres al-Islam di Yogyakarta pada 1925. Akhirnya, pihak pesantren juga tidak dilibatkan sebagai delegasi dalam Muktamar 'Alam Islami (Kongres Islam Internasional) yang diadakan di Makkah dimana kongres akan mengesahkan upaya pemerintah kerajaan Saudi Arabia. ${ }^{9}$ Kalangan pesantren akhirnya merespons dengan membuat delegasi sendiri yang disebut Komite Hijaz yang dipimpin oleh KH. Wahab Hasbullah karena adanya upaya untuk menegakkan kebebasan bermazhab dan kepedulian terhadap warisan Islam klasik. ${ }^{10}$

Berangkat dari komite dan berbagai organisasi yang bersifat embrional, seperti Nahdlah al-Wathan (semangat kebangsaan), Nahdlah al-Tujjar (kebangkitan ekonomi), dan Taswir al-Afkar (pembaruan pemikiran), akhirnya dibentuk organisasi yang diharapkan dapat menjadi wadah tempat berhimpun dan memperjuangkan gagasan-gagasan mereka dalam berbagai bidang, dan diberi nama Nahdlatul Ulama (Kebangkitan Ulama) pada tanggal 16 Rajab $1344 \mathrm{H}$ (31 Januari 1926) yang pada awal berdirinya dipimpin oleh KH. Hasyim Asy'ari sebagai Ra'is Akbar.

Istilah nahdah berarti kemampuan, kekuatan, dan loncatan atau terobosan dalam mengupayakan kemajuan. Sedangkan secara 
terminologi adalah menerima segala aktivitas kemajuan umat yang berperadaban lama dari sisi peradaban yang lebih baru disertai kemampuan melakukan rekonstruksi dan reformasi. ${ }^{11}$

Dengan demikian, istilah nahdlah menuntut adanya kesadaran dan pengertian fakta historis secara khusus, dan dibutuhkan kapasitas kemampuan untuk melakukan renovasi kondisi yang kurang relevan berdasarkan fakta sejarah baik secara kultural maupun pemikiran. Aplikasi term tersebut diformulasikan dalam kaidah 'mempertahankan hal-hal lama yang masih baik dan mengambil hal-hal baru yang lebih baik'. ${ }^{12}$

Sementara ulama adalah bentuk jamak dari 'alîm yang berarti tahu, mengerti, dan pandai. Kata 'alîm terulang dalam Alquran sebanyak 106 kali, sementara kata ulama terulang sebanyak dua kali. Pertama, konteksnya terkait dengan ajakan untuk menggunakan potensinya untuk memperhatikan, mengelaborasi dan mengeksplorasi ciptaan Allah, seperti Q.S. Fâthir/35: 28. Kedua, terkait dengan konteks kebenaran Alquran dan Nabi Muhammad SAW. sebagai penutup para nabi yang telah lama diketahui oleh Bani Israil "dan apakah tidak cukup menjadi bukti bagi mereka, bahwa para ulama Bani Israil mengetahuinya?.” Dengan demikian, berdasarkan kedua ayat di atas, pengertian ulama adalah 'orangorang yang memiliki pengetahuan tentang ayat-ayat Allah SWT., baik ayat kauniah maupun qauliyah.

Sejarah kelahiran NU dimotori oleh para ulama pengasuh pondok pesantren, sehingga identitas dan nilai-nilai yang dianut di pesantren turut dibawa ke dalam organisasi ini. Dengan demikian, hubungan NU dengan pesantren sangat dekat. Abdurrahman Wahid menggambarkan 'NU adalah pesantren yang tertulis luas, dan pesantren adalah NU yang tertulis kecil. ${ }^{\prime 3}$ Ungkapan ini menggambarkan bahwa NU dan pesantren tidak dapat dipisahkan. Nilai-nilai yang dianut di pesantren dengan demikian juga menjadi nilai-nilai yang dianut oleh NU, demikian juga sebaliknya. 
Nilai dasar yang menjadi identitas pesantren dan NU antara lain adalah paham Ahlussunnah Waljamaah. ${ }^{14}$ Istilah Ahlussunnah Waljamaah terdiri atas tiga perkataan: ahl, al-sunnah dan aljamâ'ah. Ahl menurut pengertian kebahasan berarti 'keluarga, kerabat, pengikut, atau golongan. ${ }^{15}$ Al-Sunnah berarti "hadis atau segala perkataan, perbuatan dan diamnya Nabi Muhammad SAW. atas suatu perbuatan sahabat, dan al-jamâ'ah mengandung makna 'kelompok' 'orang banyak' atau 'mayoritas.' Jadi, secara singkat, Ahlussunnah Waljamaah berarti 'keluarga yang terdiri atas kelompok besar masyarakat yang menjadikan hadis Nabi Muhammad SAW. sebagai pegangan hidup mereka. ${ }^{36}$

Pengertian ini sejalan dengan definisi yang diungkapkan oleh Abdus Syukur Bangilani, sebagaimana dikutip Busyairi Harits, yang menyatakan, bahwa Ahlussunnah Waljamaah ialah orang-orang yang selalu berpedoman pada sunah Nabi Muhammad SAW. dan amal perbuatan para sahabatnya dalam masalah akidah keagamaan, amal-amal lahiriah serta akhlak hati. ${ }^{17}$

Ahlussunnah Waljamaah juga memiliki beberapa nama. Pertama, ahl al-hadîts wa al-sunnah, yaitu kelompok yang berpegang pada hadis dan sunnah. Kedua, Ahl al-haq wa al-sunnah, yaitu kelompok yang berpegang pada kebenaran dan sunnah. Ahlussunnah Waljamaah disebut juga dengan nama Sunni, terutama ketika aliran ini digunakan dalam istilah politik dan dihadapkan dengan mazhab Khawarij dan Syiah. ${ }^{18}$

Tidak jelas disebutkan kapan term Ahlussunnah Waljamaah muncul dan dipakai. Sebelum masa al-Asy'ari, dimana namanya kerap dilekatkan dengan aliran ini, kata $A h l$ al-Sunnah atau istilah yang identik dengan itu telah ada, seperti pernyataan wa nasabu anfusahum ila al-sunnah (mereka menisbahkan diri sebagai pengikut sunnah). Selain beberapa pernyataan yang mencerminkan keterikatan suatu kelompok kaum Muslim pada sunnah, ada sejumlah term yang melekat pada objek yang sama, seperti 
term Ahl al-hăaq wa al-dîn wa al-jamâ'ah (pemangku kebenaran, agama dan jamaah). Karena itu, sebelum mazhab al-Asy'ariyah lahir, sudah ada pihak yang menamakan dirinya istilah $A h l$ alSunnah. Tokoh utamanya adalah Ahmad bin Hanbal. Hanya saja, term Ahl al-Sunnah ini akhirnya lebih banyak dinisbahkan dengan mazhab Asy'ariyah dan Mâturîdiyah, sedangkan Ahmad

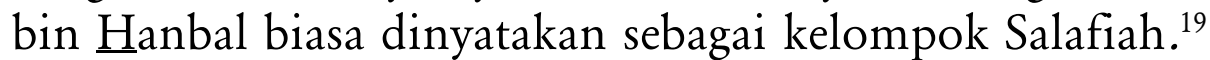

Terlepas dari uraian di atas, ternyata istilah Ahlussunnah Waljamaah itu telah diungkapkan oleh Jalâl al-Dîn al-Suyuthi yang diklaim berasal dari Ibn 'Abbâs (w. $688 \mathrm{M}$ ), dalam kitabnya al-Dur al-Mantsûr sebagai berikut: ${ }^{20}$

Ibn Abi Hâtim dan Abû Manshûr dalam kitab al-Ibânah, Khatîb dalam kitab Târîkhnya, dan al-Alkâ‘i dalam kitab alSunnah meriwayatkan dari Ibn 'Abbâs, tentang tafsir ayat surat Âli 'Imrân/5: 106, "Adapun orang-orang yang wajahnya putih berseri, adalah pengikut $A$ hl al-Sunnah wa al-Jamâ'ah. Sedangkan orang-orang yang wajahnya hitam adalah pengikut bidah dan kesesatan."

Jalâl al-Dîn al-Suyuthi juga mengungkapkan jalur lain terkait dengan penyebutan term ini, yaitu dari Mâlik dan Dailâmi, demikian juga dari Abû Nâshir al-Sajzi dalam kitab al-Ibânah yang berasal dari Sa id al-Khudri. Ia menyatakan sebagai berikut: ${ }^{21}$

Al-Khâtib dalam riwayat Mâlik dan al-Dailâmi yang berasal dari Ibn 'Umar dari Nabi Muhammad SAW. tentang tafsir surat Âli 'Imrân/5: 106, "adapun orang-orang yang wajahnya putih berseri, adalah pengikut Ahl al-Sunnah wa al-Jamâ'ah. Sedangkan orang-orang yang wajahnya hitam adalah pengikut bidah".

Kemudian Abû Nâshir al-Sajzi dalam al-Ibânah yang berasal dari Sa'id al-Khudri juga menyatakan bahwa Rasulullah SAW. sewaktu membaca surat Âli 'Imrân/5: 106 menyatakan, "adapun orang-orang yang wajahnya putih berseri, adalah pengikut Ahl 
al-Sunnah wa al-Jamâ‘ah. Sedangkan orang-orang yang wajahnya hitam adalah pengikut bidah dan kesesatan”.

Dengan demikian, berdasarkan pada argumen ini, term Ahlussunnah Waljamaah ternyata telah ada semenjak Nabi Muhammad SAW. dan sahabat dan telah disebutkan oleh para ulama dalam berbagai buku mereka. Namun, perbincangan mengenai term ini semakin intens pada era tabiin dan ulama Salaf sesudahnya, seperti khalifah 'Umar bin 'Abd al-Azîz (w. 720M), Imam Hasan bin Yasar al-Basri (w. 729 M), Imam Muhammad bin Sirin (33w. 729 M), dan Imam Sufyân bin Sa'id al-Sauri (w. 778 M). ${ }^{22}$

Ditinjau dari sudut historis, istilah Ahlussunnah Waljamaah ternyata tidak memiliki arti monolitik yang menunjuk pada satu arti, akan tetapi mengalami perubahan konotasi sesuai dengan konteks sejarah masing-masing. Setidaknya, ada tiga fase perkembangan pengertian Ahlussunnah Waljamaah yang diidentikkan pada kelompok orang dan aliran tertentu. Pertama, Ahlussunnah Waljamaah identik dengan sebutan nama kelompok ulama ahli Hadis yang lebih banyak merujuk hadis dalam menjawab masalah-masalah agama ketimbang penggunaan rasio. Kelompok ini lebih banyak tinggal di daerah Madinah dan mulai dipandang sebagai kekuatan elit intelektual yang cukup berpengaruh di masyarakat pada saat gelombang pemahaman hukum bercorak ra'y di Basrah merebak. Secara politis mereka tidak berafiliasi dengan kelompok mana pun dan sering mengambil jarak dengan urusan politik. Mereka lebih memilih integritas umat dan stabilitas sosial. $^{23}$

Pada era Khalifah 'Umar bin 'Abd al-'Azîz (103 H.), kelompok ini dirangkul sebagai kelompok pendukung khalifah untuk memperkuat posisi politiknya dengan target dapat mendinginkan atmosfir politik yang terus bergolak. ${ }^{24}$ Akan tetapi kelompok ini mulai ditinggalkan oleh penguasa Abbasiyah, terutama pada masa pemeritahan Khalifah al-Ma'mun, al-Mu'tashim, dan al- 
Watsiq yang lebih tertarik dengan pengembangan tradisi keilmuan impor dan teologi yang bersifat rasional Muktazilah. Bahkan Ahmad ibn Hanbal menjadi korban kebijakan khalifah dalam penerapan inkuisisi yang populer dengan al-mihnah. Ibn $\underline{\mathrm{H} a n b a l}$ bahkan meninggal di dalam penjara dan menjadi simbol perlawanan Ahl al-Sunnah terhadap pemerintah yang memberlakukan Muktazilah sebagai aliran resmi negara. Pada fase ini, istilah Ahlussunnah Waljamaah dipahami sebagai golongan yang memegang teguh tradisi Nabi. ${ }^{25}$

Fase kedua, istilah Ahlussunnah Waljamaah mengalami perubahan menjadi sebuah nama bagi kelompok yang mengikuti aliran teologi yang dibawa oleh Abû Hasan al-Asy ári (w. 935 M) di daerah Bashrah dan Abû Manshûr al-Mâturîdi (w. 944 M) di Samarkand. Dua tokoh Muktazilah ini membelot dan mendirikan aliran baru dan mendukung ahli hadis. ${ }^{26}$

Setelah khalifah al-Mutawakkil, salah seorang khalifah Abbasiyah, mencabut kebijakan pendahulunya yang menjadikan aliran Muktazilah sebagai aliran resmi negara di abad ke-3 Hijriyah. Pandangan al-Asy ári yang banyak membantah argumen-argumen aliran Muktazilah mendapat simpati dari kalangan Ahl al-Sunnah. Kelompok Ahl al-Sunnah saat itu sudah mulai mendapat dukungan masyarakat luas. Gerakan perlawanan yang dimainkan oleh kedua tokoh ini bukan saja berhasil membendung aliran Muktazilah, akan tetapi justru bergulir menjadi arus utama pemikiran Islam yang dominan hingga dewasa ini. Pada fase ini pengertian Ahlussunnah Waljamaah menjadi lebih sempit sebagai sebutan bagi kelompok umat yang menganut teologi Sunni yang direpresentasikan oleh aliran Asy áriyah dan pengikutnya. ${ }^{27}$

Namun dalam penggal sejarahnya, aliran Asy'ariyah pernah tidak diakui sebagai bagian dari Ahl al-Sunnah. Penolakan itu datang dari pengikut Hanabilah setelah al-Asy'ari menulis kitab Istihhsân yang berani mengkritik metode berpikir kalangan ahli 
hadis yang cenderung literalis dan antromorfis. Pada saat itu, al-Asy'ari mulai memperkenalkan pola berpikir ahli hadis yang lebih sistematis dan rasional dalam membicarakan teologi. Perseteruan ini terus berlanjut dengan satu tuduhan bahwa al-Asy'ari dinilai lebih mirip Muktazilah karena masih menerapkan takwil dalam memahami ayat-ayat mutasyâbihat. Dampak dari perseteruan ini melahirkan dua kelompok, yaitu Ahlussunnah Waljamaah Khalaf yang didukung oleh aliran Asy'ariyah dan Mâturîdiyah, dan Ahlussunnah Waljamaah Salaf yang didukung oleh kelompok ahli hadis pengikut Ahmad ibn $\underline{\text { Hanbal. }} .^{28}$

Fase ketiga, istilah Ahlussunnah Waljamaah berkembang menjadi pengelompokan entitas politik yang membedakan dirinya dari kekuatan politik Syiah. Untuk pengertian ini, Ahlussunnah Waljamaah berarti kelompok Muslim Ahl al-Sunnah yang lebih dikenal dengan sebutan Sunni yang sering bertentangan dengan Syiah. ${ }^{29}$

Saat ini, di intern Sunni sendiri, istilah Ahlussunnah Waljamaah menjadi rebutan antara kelompok Ahlussunnah Waljamaah Khalaf yang didukung oleh kelompok Islam di luar Saudi Arabia dan Ahlussunnah Waljamaah Salaf yang disokong oleh aliran Wahabiyah di Saudi Arabia. ${ }^{30}$

Merujuk pada kategori di atas, kelihatannya NU sebagai organisasi yang merujuk pada nilai-nilai dasar yang dianut para kiai pesantren bisa dikategorikan pada Ahlussunnah Waljamaah Khalaf. Di awal kelahirannya, sebagaimana terdapat dalam Qanun Asasi (Anggaran Dasar) NU, Ahlussunnah Waljamaah (Aswaja) diformulasikan sebagai aliran yang mendasarkan pemahamannya dalam bidang fikih kepada empat mazhab, yaitu Malikiyah,

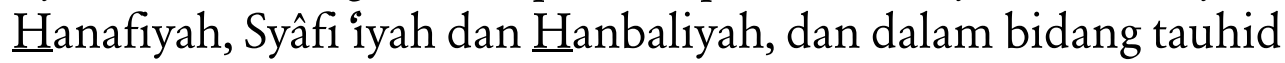
kepada Abû al-Hasan Asy'ari dan Abû Manshûr Mâturîdi, sedangkan dalam bidang tasawuf kepada al-Ghazâlî dan Junaid al-Baghdâdî. ${ }^{31}$ 


\section{NU dan Tradisi Sunni}

Seiring dengan perkembangan NU, di tangan para tokohnya, pemahaman term Ahlussunnah Waljamaah (Aswaja) mengalami perkembangan. Istilah ini lebih dipahami sebagai sebuah metode (manhaj) berpikir. Said Aqil Siradj misalnya, mendefinisikan Aswaja sebagai orang-orang yang memiliki metode berpikir keagamaan yang mencakup semua aspek kehidupan yang berlandaskan atas dasar-dasar moderasi, menjaga keseimbangan, dan toleran. ${ }^{32}$

Menurut Siradj, moderasi Aswaja terlihat pada metode pengambilan (istinbâth) hukum yang tidak hanya memakai nash, tetapi juga memperhatikan kedudukan akal. Begitu pula dalam wacana berpikir senantiasa menjembatani antara wahyu dengan akal (al-ra'y). Metode (manhaj) seperti inilah yang diterapkan oleh pendiri fikih mazhab empat serta generasi era berikutnya dalam menemukan hukum-hukum (fikih). ${ }^{33}$

Adapun sifat netral (tawâzun) Aswaja berhubungan dengan sikap mereka dalam bidang politik. Aswaja tidak terlalu membenarkan kelompok garis keras (ekstrim). Akan tetapi, jika berhadapan dengan penguasa politik yang zalim, mereka tidak segan-segan mengambil jarak dan mengadakan aliansi. Dengan kata lain, suatu saat mereka bisa akomodatif, suatu saat bisa lebih dari itu meskipun masih dalam batas tawâzun. ${ }^{34}$

Sedangkan keseimbangan (ta âduI) Aswaja terefleksikan pada kiprah mereka dalam kehidupan sosial, cara mereka bergaul serta kondisi sosial budaya mereka. Begitu pula sikap toleran (tasâmuh ) Asawaja tampak dalam pergaulan dengan sesama Muslim yang tidak mengkafirkan ahl al-qiblat serta senantiasa ber-tasâmuh $\underline{\underline{h}}$ terhadap sesama Muslim maupun umat manusia pada umumnya. ${ }^{35}$

Dinamika Ahlussunnah Waljamaah tidak hanya sampai di sini, tokoh-tokoh NU lain juga telah banyak menyampaikan pemikiran dan gagasannya menyangkut term ini sebagai upaya 
kontektualisasi prinsip dasar tersebut sehingga tetap aktual dan dapat menjawab tantangan perubahan. Hasyim Muzadi misalnya menyatakan, ${ }^{36}$ bahwa prinsip Ahlussunnah Waljamaah mengandung dua elemen penting yang sebenarnya tercermin dari istilahnya sendiri. Ahlussunnah Waljamaah menggambarkan bagaimana agama harus ditafsirkan dan dipraktikkan berdasarkan ajaran Rasulullah SAW., sebagai kebalikan ahl al-bid'ah. Kehidupan Rasulullah sudah pasti tidak mungkin keluar dari dimensi ruang dan waktu yang punya "keterbatasan" untuk dijadikan pedoman dalam memahami Islam dikarenakan dua hal. ${ }^{37}$

Pertama, apa yang disampaikannya sebagai kehendak Ilahi untuk mengatur sekaligus memaknai kehidupan umat manusia bisa jadi hanya mencakup kaidah-kaidah dasar serta normanorma ideal yang bersifat universal. Kalaupun berbicara pada dataran operasional, puluhan tahun masa yang dihabiskan Rasul terakhir tersebut tentu belum mencukupi untuk menjelaskan dan mengurai seluruh aspek realitas persoalan yang dihadapi masyarakat sepanjang masa, sehingga masih menyisakan ruang perdebatan. Kedua, sebagian kompleksitas masalah yang dicover oleh titah Tuhan melalui Rasul-Nya sangat mungkin disesuaikan dengan kebutuhan zamannya meskipun tidak boleh diartikan sebagai pembatasan Kemahatahuan Allah yang mengatasi ruang dan waktu. Artinya, kontekstualisasi ajaran agama, mau tidak mau, menjadi sebuah keniscayaan, yang di sisi lain menuntut perluasan pemaknan ajaran Islam lewat metode-metode tertentu yang berkaitan dengan istinbâth al-ahkâm demi menghindari "kebuntuan" penyesuaian masalah keagamaan.

Dengan demikian, menurut Hasyim Muzadi, Ahlussunnah Waljamaah pada dasarnya berupaya mengawinkan antara berbagai living tradition yang bersifat nisbi dan merupakan bagian dari fakta sejarah manusia di sepanjang waktu dengan ketauhidan Islam yang bersifat mutlak dan tidak mengalami perubahan 
sampai kapan pun. Perkawinan ini seakan mencoba menjelaskan bagaimana cara menjalankan syariat Islam ketika doktrin agama yang bersifat normatif dan kering harus diturunkan ke dataran empirik yang dinamis dan menjelma menjadi suatu tradisi, serta menekankan bahwa tradisi awal Islam di masa Rasulullah dan para sahabatnya bukanlah episode sejarah yang pantas di buang jauh-jauh, melainkan mesti diwarisi sesuai dengan tingkat relevansi dan kebutuhan aktual pada masa yang lebih belakangan, tak terkecuali dalam fase sejarah yang sedang dijalani saat ini. ${ }^{38}$

Karena itu, jika membincangkan Ahlussunnah Waljamaah yang sering disebut kaum tradisionalis atau kelompok pembela tradisi keagamaan, maka yang pertama kali layak dikupas adalah upaya penelusuran sejarah keberagamaan, karena tidak bisa dihindari diri dari kenyataan bahwa setiap tradisi yang berbentuk pasti ada faktor kesejarahan yang mengitarinya. ${ }^{39}$

Bertolak dari pemikiran tersebut, NU menurut Hasyim Muzadi berusaha menyambung kembali tali keilmuan yang mengikat fase-fase sejarah dari generasi ke generasi semenjak zaman Nabi untuk dijadikan bahan-bahan bangunan tradisi keberagamaan sesuai kebutuhan kekinian. Dengan kesadaran semacam ini maka lahirlah kredo al-muhhâfazhah 'ala qadîm alshâlih wa al-akhzu bi al-jadîd al-ashlâh (mempertahankan tradisi lama yang masih relevan, dan responsif terhadap gagasan baru yang lebih baik dan lebih relevan).

Kredo yang sangat populer di kalangan NU ini ingin menegaskan bahwa setiap khazanah lama "layak" digunakan sebagai referensi untuk menyikapi realitas kehidupan di kemudian hari. Sebaliknya dari sekian banyak tradisi salaf itu selalu ada kemungkinan kebenaran dan kebaikan yang dapat diambil sebagai pedoman. Adapun hal-hal yang baru juga tidak perlu dijauhi, apalagi dimusuhi, selama esensi yang ditawarkannya bermuara pada kemaslahatan. Secara tidak langsung, NU menganggap ada keharusan untuk 
menjaga semangat yang dibawa oleh khazanah lama dengan ketentuan bahwa fungsi positif di dalamnya memang masih diperlukan demi keseimbangan keberagamaan masyarakat, serta menempelkan warna baru yang diyakini dapat mengantar ke arah kesempurnaan. ${ }^{40}$

Selain itu, prinsip ini juga menjadikan NU sangat lentur beradaptasi dengan budaya lokal. Budaya lokal dengan beragam pemikiran yang ada di dalamnya dilibatkan dalam menafsirkan teks ajaran agama. Proses kontekstualisasi ajaran agama ini tentunya tetap dilakukan atas pertimbangan yang ashlâh (baik) dan yang aqbah (buruk). Terkait dengan hal ini, Hasyim Muzadi menyatakan "seandainya faktor lokal secara keseluruhan ditolak untuk diintegrasikan dalam pemikiran agama, atas nama kemurnian ajaran, tentu saja Islam akan 'kehilangan' kontekstualitasnya dan tampak sebagai ajaran yang rigid. Di samping itu, Islam akan dianggap 'gagal' dalam mempertemukan nash dan perkembangan pemikiran. $\mathrm{Hal}$ ini mengakibatkan mandegnya kreatifitas berpikir para pemeluknya." ${ }^{41}$

Uraian di atas menggambarkan bahwa pada saat ini istilah Ahlussunnah Waljamaah versi NU telah mengalami perkembangan, tidak hanya dipahami sebagai landasan 'ubûdiyah, tetapi juga sebagai metode (mahaj) berpikir. Sebagai sebuah manhaj, paham Ahlussunnah Waljamaah menjadi lebih rasional dan dinamis dalam menyikapi perkembangan masyarakat, dan menjadikan NU lebih luwes berhadapan dengan tantangan keumatan dan keindonesiaan.

\section{Falsafah Pendidikan NU}

Landasan adalah dasar tempat berpijak sehingga sesuatu itu dapat berdiri dengan kokoh. Suatu bangunan harus memiliki pondasi yang kuat sebagai landasan supaya dapat berdiri dengan 
kokoh. Landasan berfungsi sebagai asal dan sumber tempat merujuk sekaligus juga mengandung arah dan tujuan yang akan dicapai. Pendidikan sebagai proses timbal balik antara pendidik dan peserta didik dengan melibatkan berbagai faktor pendidikan lainnya, diselenggarakan untuk menggapai tujuan pendidikan tentu mempunyai landasan yang berasal dari nilai-nilai tertentu sebagai cerminan filsafat pendidikan tersebut.

Ontologi adalah teori tentang 'ada', yaitu tentang apa yang dipikirkan, yang menjadi obyek filsafat. Menurut Jujun S. Suriasumantri, ontologi terkait tentang hakikat apa yang dikaji, atau jawaban dari "apakah hakikat kenyataan ini sebenar-benarnya?" ${ }^{42}$ Kajian ontologi mengacu kepada realita. Menurut Imam Barnadib, sebagaimana dikutip oleh Jalaluddin, realita ialah kenyataan, yang seterusnya mengarah kepada masalah kebenaran. Kebenaran akan muncul jika orang telah mampu menarik konklusi bahwa ilmu yang diraih telah nyata. ${ }^{43}$

Dengan demikian landasan ontologi di sini dimaknai sebagai apa yang menjadi dasar berpijak bagi konsep pendidikan dalam organisasi NU. Landasan itu diadopsi menjadi nilai-nilai yang mengkonstruk sistem pendidikan NU, baik dalam tataran konsep maupun aplikatif.

Merujuk pada uraian sebelumnya dapat dilihat landasan yang menjadi dasar pendidikan NU. Pijakannya berasal dari prinsip dasar (Qanun Asasi) NU yang intinya tertuang dalam konsep Ahlussunnah Waljamaah yang dipahami bukan hanya sebagai ketentuan bermazhab secara rigid, tetapi lebih pada sebuah manhaj yang bersifat dinamis.

Karakter pemahaman dinamis terhadap konsep Ahlussunnah Waljamaah tersebut diartikan sebagai perlunya pembaharuan terus-menerus yang harus berlangsung dengan prinsip tawâzun (moderat), ta âdul (keseimbangan) dan tasâmuh (toleransi). Model 
pembaharuan seperti ini tertuang dalam kaidah terkenal "mempertahankan tradisi lama yang masih relevan, dan responsif terhadap gagasan baru yang lebih baik dan lebih relevan.”

Dengan demikian, landasan di atas menegaskan bahwa NU sebagai organisasi telah meletakkan dasar-dasar pendidikan yang selalu siap melakukan upaya rekonstruksi pemahaman terhadap perkembangan dunia pendidikan sehingga tetap relevan dan dapat menjawab tuntutan masa kini dan masa depan.

Hal lain yang menarik dari landasan ini adalah semangat adaptasinya terhadap budaya di tengah upaya modernisasi, bukan memusuhi, bahkan secara implisit menyiratkan arti perlunya upaya pemaduan antara keduanya, yang dalam kancah pemikiran Islam disebut new modernisme.

Sebagaimana diketahui bahwa pemaduan antara tradisi dan modernitas dalam wacana pemikiran Barat senantiasa dipertentangkan akibat pengaruh konsep Barat yang memetakan modernisasi membentur tradisi. Sementara itu pemikir neo-modernis berpandangan bahwa modernisasi merupakan mata rantai dari tradisi, sehingga perlu upaya mengintegrasikan tradisi dengan modernisasi. ${ }^{44}$

Landasan pendidikan NU ini berikutnya diturunkan menjadi Anggaran Dasar NU sebagaimana terdapat pada Pasal IX Anggaran Dasar NU sebagai berikut "Di bidang pendidikan, pengajaran dan kebudayaan mengupayakan terwujudnya penyelenggaraan pendidikan dan pengajaran serta pengembangan kebudayaan yang sesuai dengan ajaran Islam untuk membina umat agar menjadi Muslim yang takwa, berbudi luhur, berpengetahuan luas dan terampil, serta berguna bagi agama, bangsa dan negara.”

Konsepsi NU mengenai pendidikan dalam Anggaran Dasar ini secara eksplisit menjelaskan visi NU dalam bidang pendidikan, yaitu selain konsern menyelenggarakan pendidikan dan pengajaran, juga fokus 'mengembangkan kebudayaan yang sesuai dengan ajaran 
Islam'. Kelihatannya ungkapan ini merupakan penegasan sikap adaptif NU pada kebudayaan yang berkembang di tengah-tengah masyarakat. Kebudayaan masyarakat tidak dimusuhi, tetapi diarahkan dan diislamisasi, bahkan jika tidak bertentangan dengan ajaran Islam dipatenkan menjadi tradisi yang baik. Hal ini dimungkinkan karena metodologi istinbat hukum dalam NU begitu kaya. Dalam buku-buku Qawâ'id al-Fiqhiyah yang diajarkan di lingkungan lembaga pendidikan NU dikenal undang-undang al-âdat almuhakkamah (adat dapat dijadikan sumber dalam menetapkan hukum). Karenanya, tidak mengherankan jika di lingkungan NU berkembang berbagai tradisi keberagamaan sebagai bagian dari 'Islam' itu sendiri.

Ungkapan “ajaran Islam” sebagai pondasi pendidikan NU dalam Pasal IX Anggaran Dasar NU ini di satu sisi juga merupakan penegasan bahwa NU sangat menjunjung tinggi ajaran Islam sebagai referensi dalam mengembangkan pendidikan, namun pada sisi lain menegaskan bahwa, ajaran Islam versi NU mengacu pada Qanun Asasi NU sebagaimana dirumuskan pendirinya, Hasyim Asy'ari, yaitu berpaham Ahlussunnah Waljamaah. ${ }^{45}$

Dengan melihat landasan ini, dapat dipahami alasan NU menetapkan tujuan pendidikan seperti dikemukakan di atas, yang lebih spesifik dapat dilihat pada Lembaga Pendidikan Ma'arif Nahdlatul Ulama (PP LP Ma'arif NU). Lembaga ini merupakan satu di antara aparat departementasi dalam organisasi NU yang visinya sebagai berikut. Pertama, mengembangkan sistem pendidikan dan terus berupaya mewujudkan pendidikan yang mandiri dan membudayakan (civilitize). LP Ma'arif NU akan menjadi pusat pengembangan pendidikan bagi masyarakat, baik melalui sekolah, madrasah, perguruan tinggi, maupun pendidikan masyarakat. Kedua, merepresentasikan perjuangan pendidikan NUyang meliputi seluruh aspek kognitif, afektif, maupun psikomotorik. Ketiga, menciptakan komunitas intitusional yang mampu menjadi 
agent of educational reformation dalam upaya mencerdaskan kehidupan bangsa dan pembangunan masyarakat beradab.

Jika visi tersebut dianalisis, akan kelihatan bahwa terdapat beberapa kata kunci yang merupakan refleksi dari prinsip-prinsip dasar NU dalam mengembangkan pendidikan: mandiri, membudayakan, dan pusat pengembangan pendidikan. Visi ini juga menjelaskan pemahaman NU tentang pentingnya internalisasi filosofi nilainilai yang dianut NU baik pada aspek kognitif (pemikiran), afektif (sikap), maupun psikomotorik (keterampilan).

Bangsa yang cerdas dan masyarakat beradab adalah ultimate goal dari pendidikan NU. Prinsip keseimbangan terejawantah dalam tujuan ini dengan melihat urgensi keseimbangan ( $t a$ 'âduI) dalam tujuan pendidikan yang ingin diperjuangkan organisasi ini. Kecerdasan dan adab adalah dua aspek yang sama-sama urgen dalam pembangunan bangsa dan masyarakat. Mengabaikan salah satu dari keduanya akan menyebabkan ketimpangan bahkan akan menyebabkan bencana bagi masa depan kehidupan berbangsa dan bernegara.

\section{Falsafah Pendidikan Pesantren Musthafawiyah}

Pesantren Musthafawiyah adalah satu di antara pesantren paling tua di Sumatera Utara, dan berdiri pada tanggal 12 Desember 1912. Pendirinya, Syekh Musthafa Husein merupakan pendiri Nahdlatul Ulama di Keresidenan Tapanuli. NU pertama sekali berkembang di kawasan ini, kemudian akhirnya berpusat di Medan, Sumatera Timur. Bersama Syekh Hasan Maksum, ${ }^{46}$ Syekh Musthafa Husein pernah menjadi penasihat organisasi Al Washliyah yang berkembang pesat di Sumatera Timur, dimana organisasi ini didirikan oleh pelajar Maktab Islamiyah Tapanuli (MIT), dan Madrasah Hasaniyah, 30 Nopember $1930 .{ }^{47}$ Tetapi, setelah melakukan perjalanan ke Pulau Jawa, akhirnya pendiri pesantren 
ini memutuskan bergabung dengan NU dan menjadi pendiri awal organisasi yang didirikan oleh Syekh Hasyim Asy'ari ini di Sumatera Utara. Untuk selanjutnya, Syekh Musthafa Husein mendorong para santrinya untuk menjadi pengikut NU. Ia sendiri bahkan terpilih menjadi anggota Majelis Konstituante hasil Pemilu 1955 dari Partai NU, meskipun ia telah wafat sebelum sempat dilantik. Alumni Pesantren Musthafawiyah kerap merupakan anggota NU, dan banyak tokoh NU di Sumatera Utara merupakan alumni pesantren ini. ${ }^{48}$

Pada awalnya, Pesantren Musthafawiyah didirikan di desa Tano Bato. Tetapi, belakangan pesantren ini dipindahkan ke desa Purba Baru setelah banjir bandang meluluhlantakkan desa Tano Bato pada tanggal 28 November 1915. Desa Purba Baru merupakan salah satu desa di kecamatan Lembah Sorik Marapi. Ibukota kecamatan ini adalah Pasar Maga, Kabupaten Mandailing Natal, Propinsi Sumatera Utara. Desa Purba Baru berada di antara dua bukit, dalam bahasa Mandailing disebut tor, yaitu Tor Roburan di sebelah barat dan Tor Aek Tapus di sebelah timur. Di desa ini terdapat sungai, dalam bahasa Mandailing disebut aek, yaitu Aek Singolot yang mengandung zat belerang karena berasal dari gunung Sorik Marapi yang merupakan gunung aktif, dan bermuara ke sungai Batang Gadis, atau dalam bahasa Mandailing Aek Godang di desa Aek Godang yang bertetangga dengan desa Purba Baru. Sungai lain yang berada di desa Purba Baru, tepatnya di sebelah timur, adalah Aek Tapus yang alirannya menyusuri Tor Aek Tapus. Desa Purba Baru berjarak 17 kilometer dari Kota Panyabungan yang merupakan ibukota dari Kabupaten Mandailing Natal. Dari Kota Padangsidimpuan berjarak sekitar 90 kilometer, dari Kota Medan berjarak 500 kilometer, dan dari Kota Bukittinggi berjarak 247 kilometer. ${ }^{49}$

Sejak berdiri pada tahun 1912 sampai tahun 1955, kepemimpinan 
pesantren dipegang oleh Syekh Musthafa Husein. Dalam periode ini, Syekh Musthafa Husein memegang kepemimpinan tunggal (single leader). Ia hanya dibantu oleh seorang sekretaris dan bendahara dalam menjalankan tugas-tugas di pesantren. Sampai menjelang akhir jabatannya, ia telah mewariskan 9 ruang belajar dan 450 orang santri. ${ }^{50}$

Setelah Syekh Musthafa Husein wafat, jabatan mudir(pimpinan) pesantren telah mengalami pergantian sebanyak 3 kali. Pertama, H. Abdullah Musthafa (1955-1995). Kedua, H. Abdul Khalik Nasution (1995-2004). Ketiga, H. Musthafa Bakri (2004sekarang). Sedangkan jabatan Râ'is al-Mu'allimîn (kepemimpinan edukatif) juga telah mengalami pergantian sebanyak 6 kali, dimulai dari Syekh Abdul Halim Khatib (1955-1985), Syekh Syamsuddin Hasibuan (1985-1991), Syekh H. M. Yunus Nasution (1991-1992), Syekh H. Mukhtar Siregar (1992-2003), Syekh Umar Lubis (20032010), sampai H. M. Yakub Lubis (2010-sekarang).

Berdasarkan gagasan Muhammad Bahri Ghazali tentang kategori pesantren, ${ }^{51}$ pesantren Musthafawiyah bisa dikategorikan dengan pesantren tradisional. Ada tiga karakteristik pesantren tradisional seperti dikemukakan dalam karyanya. Pertama, mempertahankan bentuk asalnya. Kedua, dari sisi kurikulum pembelajaran merujuk pada kitab-kitab yang ditulis oleh ulama-ulama abad 15. Ketiga, terus mempertahankan sistem halaqah dalam kegiatan pembelajaran ekstra kurikuler. $^{52}$

Sebagai pesantren yang secara tegas menyatakan menganut paham Ahlussunnah Waljamaah, kendatipun secara struktural tidak berafiliasi dengan NU, menarik untuk dikaji sejauhmana landasan pendidikan NU mewarnai kegiatan pendidikan di pesantren tertua di Sumatera Utara ini. Kemudian apakah prinsipprinsip seperti al-muhâfazhah 'ala qadîm al-shâlih wa al-akhzu bi al-jadîd al-ashlâh, tawâzun, ta'âdul, dan tasâmun yang merupakan landasan ontologi pendidikan NU menjadi nilai-nilai dasar 
yang dianut di pesantren ini.

\section{Prinsip Ahl al-Sunnah wa al-Jamâ'ah}

Mengacu pada profil pesantren Musthafawiyah ditemukan bahwa prinsip Ahlussunnah Waljamaah merupakan paham keagamaan yang dianut di pesantren ini. Tetapi prinsip tersebut tidak sepenuhnya mencerminkan sebagaimana dipahami pada organisasi NU. Ahlussunnah Waljamaah versi pesantren Musthafawiyah dalam bidang tauhid berpedoman pada aliran Asy'ariyah, dalam bidang fikih berpedoman pada mazhab Syâfíi, dan dalam bidang tasawuf cenderung pada aliran al-Ghazâlî. Prinsip tersebut sebagaimana terdapat dalam tujuan pesantren ini adalah "mencetak ulama yang berakhlak mulia berdasarkan akidah Ahlussunnah Waljamaah dan bermazhab Syâfi i. 1 ." Sementara visinya adalah "kompeten di bidang ilmu, mantap pada keimanan, tekun dalam ibadah, ihhsân setiap saat, cekatan dalam berpikir, terampil pada urusan agama, dan panutan di tengah masyarakat”. Karenanya, paham yang dikembangkan pesantren ini adalah paham Islam moderat, dan bertentangan dengan paham radikal. ${ }^{54}$

\section{Al-Muhâfazhah 'ala Qadîm al-Shâlih wa al-Akhzu bi al-Jadîd al-Ashlâh}

Prinsip al-muhâfazhah 'ala qadîm al-shâlih wa al-akhzu bi al-jadîd al-ashlâh sangat dikenal di Pesantren Musthafawiyah. Dalam beberapa kondisi dan situasi, prinsip ini dirujuk sebagai legitimasi tindakan pembaharuan. Perubahan sistem pendidikan halaqah menjadi klasikal pada awal berdirinya pesantren Musthafawiyah kelihatannya salah satu manifestasi kaidah tersebut. Kemudian hasil konferensi civitas pesantren dengan alumni pada tahun 1952 yang menyimpulkan perlunya memasukkan mata kuliah 
umum ke dalam kurikulum pesantren merupakan hal lain yang cukup menarik untuk diamati sebagai bentuk pembaharuan. ${ }^{55}$ Prinsip ini menjadi legalitas yang kuat atas segala usaha rekonstruksi di Pesantren Musthafawiyah. Kebebasan membentuk model pesantren (sekolah) adalah keniscayaan, asalkan tidak terlepas dari bingkai al-ashlâh (lebih baik). Demikian pula, tatkala dunia pesantren mesti melakukan rekonstruksi sebagai dampak dari kemajuan di era modern, aspek al-ashlâh akan menjadi poin utama yang harus dijunjung tinggi.

Namun, tidak adanya perubahan "kurikulum pembelajaran" yang terdapat di Pesantren Musthafawiyah sejak didirikan hingga saat ini kelihatannya tidak sejalan dengan prinsip tersebut. Kurikulum yang ditetapkan oleh Syekh Musthafa Husein dianggap formulasi final dari ajaran Alquran dan Sunah Nabi dan alshâlih (salih) di setiap zaman dan tempat. ${ }^{56}$ Ia dipandang hampir sempurna dan sulit untuk dikritik. Bahkan, mayoritas warga pesantren menganggapnya sesuatu yang sakral sehingga tidak perlu direformulasi dan upaya ke arah itu dianggap kedurhakaan kepada Syekh Musthafa Husein. Padahal, pensakralan seperti ini telah keluar dari semangat prinsip dasar yang selalu didengungdengungkan di Pesantren Mustafawiyah dan membuat kondisi santri menjadi stagnan dan mengikis kreatifitas santri.

\section{Kemandirian}

Kemampuan pesantren Musthafawiyah bertahan hingga usianya yang keseratus tahun di tengah kondisi ekonomi yang carut marut dan di bawah tekanan Kolonial Belanda yang menguasai semua sektor kehidupan selama tiga setengah abad pada awal perkembangannya merupakan bentuk kemandirian pesantren ini. Hal ini sekaligus menunjukkan adanya sejumlah nilai dan kelebihan yang dimilikinya dibandingkan dengan lembaga lain. 
Di antara nilai itu adalah pola kehidupannya yang unik. Bentuk keunikan itu antara lain terletak pada penanaman kemandirian hidup kepada para santri yang dilakukan secara terus-menerus sejak terdaftar di Pesantren Musthafawiyah. Para santri secara mandiri dituntut mampu menata hidupnya, mulai dari menyuci baju sendiri, memasak sendiri, dan menata waktu dengan baik sehingga dapat mengikuti proses pembelajaran di kelas dan di berbagai halaqah yang terdapat di lembaga ini. ${ }^{57}$

Berbagai upaya dilakukan oleh pesantren ini demi mengupayakan kemandirian, baik terkait dengan pembiayaan operasional pesantren maupun pemenuhan kebutuhan finansial para pengelola dan dewan guru pesantren, dan potensi ekonomi itu dibingkai dan dikembangkan lewat gerakan pendirian koperasi dengan badan hukum tertanggal 25 Januari 1936. Pendirian koperasi ini dapat menjadi salah satu solusi bagi para santri yang kurang mampu dari sisi finansial dan tetap dapat melanjutkan studinya di Pesantren Musthafawiyah. ${ }^{58}$

\section{Tawâzun (Netral)}

Sikap tawâzun(netral) Aswaja bermakna tidak terlalu membenarkan barisan garis keras (ekstrim). Hanya saja, suatu ketika mereka mampu bersikap akomodatif, bahkan suatu saat dapat lebih dari sikap itu, kendati masih dalam batas tawâzun. ${ }^{59}$ Sikap netral (tawâzun) Pesantren Musthafawiyah dapat dilihat pada sikap akomodatif pendiri pesantren ini pada pemerintahan Hindia Belanda. Syekh Musthafa Husein mendukung program-program baik yang dikeluarkan oleh Hindia Belanda apalagi dalam bidang pendidikan dan ekonomi yang bertujuan memperkuat ekonomi umat, dan menerima bintang emas dari Kolonial Belanda sebagai penghargaan atas jasa-jasa Syekh Musthafa Husein dalam bidang ini. Namun pada saat lain, ia bersama ulama di masanya juga pernah mengeluarkan fatwa "wajib bela negara" sebagai bentuk 
perlawanan atas hasrat Hindia Belanda yang ingin menjajah Indonesia kembali setelah merdeka pada tahun $1945 .{ }^{60}$

\section{Ta'âdul (Keseimbangan)}

Potret keseimbangan (ta âdul) Aswaja di Pesantren Musthafawiyah terefleksi pada kiprah warga pesantren dalam kehidupan sosial yang berupaya menyeimbangkan kesalehan individual dan kesalehan sosial. Cara mereka bergaul juga mencerminkan karakter saleh dan berupaya mempraktikkan dan mendakwahkannya kepada masyarakat sehingga tercipta masyarakat yang Qurani demi menjaga keseimbangan alam semesta.

\section{Tasâmuh (Toleran)}

Sikap toleran (tasâmuh ) Aswaja dalam pergaulan dengan sesama Muslim yang tidak mengkafirkan ahl al-qiblat serta selalu ber-tasâmuh terhadap sesama Muslim dan non-Muslim serta umat manusia pada umumnya dapat disaksikan pada sejarah pendiri Pesantren Musthafawiyah yang bersahabat dengan siapa saja, bahkan dengan orang yang berbeda agama. Salah seorang teman baiknya adalah penganut agama Kristen yang bernama Dr. F. L. Tobing, yang menjabat sebagai pimpinan rumah sakit zending Panyabungan. Bahkan belakangan Syekh Musthafa Husein memintanya mengajar di Madrasah Musthafawiyah. ${ }^{61}$ Fakta lain yang perlu dikemukakan terkait dengan hal ini adalah, bahwa pada masa kepemimpinan Syekh Musthafa Husein, terdapat dua orang guru beragama Kristen yang mengajar di Madrasah Musthafawiyah. Bidang studi yang mereka asuh adalah bahasa Inggris dan bahasa Belanda." ${ }^{2}$ Sikap toleran Syekh Musthafa Husein kepada non-Muslim ini terkadang bertentangan dengan mainstream pemahaman umat di masanya, bahkan mainstream pemahaman teman-temannya sesama ulama. Sebab, dalam pemahaman- 
nya relasi dan kerjasama harus dibangun bukan saja terbatas pada saudara satu agama, tetapi kepada skala yang lebih luas, lintas suku dan agama.

\section{Penutup}

Kajian di atas menghasilkan dua kesimpulan penting. Pertama, pendidikan yang dikembangkan oleh organisasi NU mengupayakan terciptanya pelaksanaan pendidikan dan pengajaran, dan pengembangan kultural yang relevan dengan prinsip-prinsip Islam demi mengantarkan umat agar dapat menjadi sosok Muslim yang bertakwa, berbudi luhur, berpengetahuan luas dan terampil, serta berguna bagi agama, bangsa dan negara. Prinsip yang menjadi landasan pendidikan NU adalah Ahlussunnah Waljamaah yang dipahami tidak hanya sebagai pedoman bermazhab, tetapi juga sebagai sebuah manhaj (metode) berpikir yang bersifat dinamis. Prinsip lain adalah almuhâfazah bi al-qadîm al-shâlih wa al-akhzu bi al-jadîd al-ashlah yang mempertegas manhajAswaja sekaligus menekankan mainstream warga NU dalam merespons tradisi dan modernitas, termasuk bidang pendidikan. Pendidikan NU dikemas di atas prinsipprinsip tawâzun (moderat), ta âdul (seimbang) dan tasâmuh (toleran). Dinamika perkembangan dunia pendidikan juga direspons dan diperjuangkan dengan memperhatikan prinsip-prinsip tersebut. Kedua, Pesantren Musthafawiyah sebagai salah satu pesantren yang paling tua di Sumatera Utara merupakan pesantren yang secara kultural berafiliasi dengan NU (tetapi tidak secara struktural), dan mengembangkan paham yang diusung oleh organisasi Islam tersebut. Sebagaimana NU, Pesantren Musthafawiyah ikut menegakkan prinsip yang dikembangkan oleh NU. Prinsip-prinsip seperti al-muhâfazhah 'ala qadîm al-shâlih wa al-akhzu bi al-jadîd alashlâh, tawâzun, ta'âdul, dan tasâmu $\underline{h}$ akhirnya menjadi nilainilai dasar yang dianut oleh pesantren ini. Kajian ini semakin memperkuat kesimpulan sejumlah peneliti bahwa pesantren 
tidak mengajarkan dan mengembangkan paham radikal, melainkan mengusung gagasan Islam moderat.

\section{Pustaka Acuan}

Al Rasyidin. "Pembelajaran Kitab Kuning di Pesantren Musthafawiyah, Mandailing Natal," dalam Journal of Contemporary Islam and Muslim Societies, Vol. 1, No. 1, 2017.

Al-Suyuthi, Jalâl al-Dîn. Al-Dur al-Mantsûr. Beirut: Dâr al-Fikr, 1993.

Bruinessen, Martin Van. NU: Tradisi, Relasi-relasi Kuasa, Pencarian Wacana Baru. Yogyakarta: LKiS, 1999.

Burhanudin, Mamat S. "Ahl as-Sunnah wa al-Jama'ah dan Dakwah Islam di Indonesia," dalam Jurnal Bimas Islam. Jakarta: 2008.

Bush, Robin. Nahdlatul Ulama and the Struggle for Power within Islam and Politics in Indonesia. Singapore: ISEAS, 2009.

Chalim, Asep Saifuddin. Membumikan Aswaja. Surabaya: Khalista, 2012.

Departemen Agama RI. Ensiklopedi Islam di Indonesia. Jakarta: Departemen Agama RI., 1993.

Gazali, Muhammad Bahri. Pendidikan Pesantren Berwawasan Lingkungan: Kasus Pondok Pesantren An-Nuqayah GulukGuluk Sumenep Madura. Jakarta: Pedoman Ilmu, 2001.

Harits, Busyairi. Islam NU: Mengawal Tradisi Sunni Indonesia. Surabaya: Khalista, 2010.

Ismail, Faisal. "The Nahdlatul Ulama: Its Early History and Contribution to the Establishment of Indonesian State," dalam Journal of Indonesian Islam, Vol. 5, No. 2, 2011.

Ja'far. "Tarekat dan Gerakan Sosial Keagamaan Shaykh Hasan Maksum," dalam Teosofi: Jurnal Tasawuf dan Pemikiran Islam, Vol. 5, No. 2, 2015. 
Ja'far. "Peran Al Jam'iyatul Washliyah dalam Merevitalisasi Madhhab Shafi'i di Era Kontemporer," dalam Justicia Islamica: Jurnal Kajian Hukum dan Sosial, Vol. 13, No. 1, 2016.

Jaib, Sa'di Abu. Al-Qamus al-Fiqhi Lughatan wa Isthilahatan. Damaskus: Dâr al-Fikr, 1988.

Jalaluddin. Filsafat Pendidikan Islam. Jakarta: Kalam Mulia, 2012.

Kholil, Mohamad . "Menggagas Pesantren sebagai Pusat Peradaban Muslim di Indonesia," dalam Media Akademika, Vol. 26, No. 3, Juli 2011.

Khuluq, Lathiful. "K.H. Hasyim Asy'ari’s Contribution to Indonesian Independence," dalam Studia Islamika, Vol. 5, No. 1, 1998.

Lubis, Yusfar. Syeikh Musthafa Husein Purba Baru 1886-1955. Bandung: t.p., 1992.

Lukens-Bull, Ronald Alan. Jihad Pesantren di Mata Antropolog Amerika. Yogyakarta: Gama Media, 2004.

Lukens-Bull, Ronald. "The Traditions of Pluralism, Accomodation, and Anti-Radicalism in the Pesantren Community," dalam Journal of Indonesian Islam, Vol. 2, No. 1 Juni 2008.

Marhumah. "The Roots of Gender Bias: Misogynist Hadiths in Pesantrens," dalam Indonesian Journal of Islam and Muslim Societies, Vol 5, No 2 (2015).

Mas'ud, Abdurrahman. Dari Haramain ke Nusantara:Jejak Intelektual Arsitek Pesantren. Jakarta: Kencana, 2006.

Muzadi, Hasyim. Nahdlatul Ulama di Tengah Agenda Persoalan Bangsa. Jakarta: Logos Wacana Ilmu, 1999.

Ni'am, Syamsun. "Pesantren: the Miniature of Moderate Islam in Indonesia," dalam Indonesian Journal of Islam and Muslim Societies, Vol. 5, No. 1, 2015.

Pribadi, Yanwar. "Religious Networks in Madura: Pesantren, Nahdlatul Ulama, and Kiai as the Core of Santri Culture," dalam alJamiah: Journal of Islamic Studies, Vo. 51, No. 1, 2013. 
Pulungan, Abbas. "Nahdlatul Ulama di Luar Jawa: Perkembangan di Tanah Mandailing," dalam Journal of Contemporary Islam and Muslim Societies, Vol. 2, No. 1, 2018.

Qomar, Mujamil. Pesantren dari Transformasi Metodologi Menuju Demokratisasi Institusi. Jakarta: Erlangga, t.t.

Salamuddin. "Corak Teologi Syekh Musthafa Husein.” Disertasi, Pascasarjana IAIN Sumatera Utara, 20013.

Salamuddin. "Teologi Rasional Pada Pesantren Tradisional: Telaah Konsep Teologi pada Buku Daras Teologi di Pesantren Musthafawiyah," dalam MIQOT:Jurnal Ilmu-ilmu Keislaman, Vol. 38, No. 1, 2014.

Siradj, Said Aqil. Ahlussunnah Wal Jama'ah dalam Lintasan Sejarah. Yogyakarta: LKPSM, 1997.

Suma, Muhammad Amin. "Kelompok dan Gerakan,” dalam Taufik Abdullah (ed.), Ensiklopedi Tematis Dunia Islam. Jakarta: Ichtiar Baru van Hoeve, t.t.

Suriasumantri, Jujun S. Filsafat Ilmu. Jakarta: Pustaka Sinar Harapan, 2003.

Syahnan, Mhd. "Islam as a System: A Critical Analysis of Sayyid Quthb's Principle Thought," in Analytica Islamica, Vol. 4 No. 1, May 2002.

Syahnan, Mhd. Contemporary Islamic Legal Discourse: A Study of Sayyid Quthb's Fi Zhilal al-Qur'an. Medan: IAIN Press, 2010. 


\section{Catatan Akhir:}

'Sekadar contoh, lihat Ronald Lukens-Bull, "The Traditions of Pluralism, Accomodation, and Anti-Radicalism in the Pesantren Community," dalam Journal of Indonesian Islam, Vol. 2, No. 1 Juni 2008, h. 14; Yanwar Pribadi, "Religious Networks in Madura: Pesantren, Nahdlatul Ulama, and Kiai as the Core of Santri Culture," dalam alJami’ah: Journal of Islamic Studies, Vo. 51, No. 1, 2013.

"Marhumah, "The Roots of Gender Bias: Misogynist Hadiths in Pesantrens," dalam Indonesian Journal of Islam and Muslim Societies, Vol. 5, No. 2 (2015).

${ }^{3}$ Syamsun Ni'am, "Pesantren: the Miniature of Moderate Islam in Indonesia," dalam Indonesian Journal of Islam and Muslim Societies, Vol. 5, No. 1, 2015.

${ }^{4}$ Tentang NU lihat, Faisal Ismail, "The Nahdlatul Ulama: Its Early History and Contribution to the Establishment of Indonesian State," dalam Journal of Indonesian Islam, Vol. 5, No. 2 (2011).

${ }^{5}$ Lathiful Khuluq, "K.H. Hasyim Asy'ari's Contribution to Indonesian Independence," dalam Studia Islamika, Vol. 5, No. 1, 1998.

${ }^{6} \mathrm{Di}$ antara studi tentang pesantren ini, lihat kajian yang dilakukan Salamuddin, "Teologi Rasional Pada Pesantren Tradisional: Telaah Konsep Teologi pada Buku Daras Teologi di Pesantren Musthafawiyah," dalam MIQOT:Jurnal Ilmu-ilmu Keislaman, Vol. 38, No. 1, 2014; Al Rasyidin, "Pembelajaran Kitab Kuning di Pesantren Musthafawiyah, Mandailing Natal," dalam Journal of Contemporary Islam and Muslim Societies, Vol. 1, No.1, 2017.

${ }^{7}$ Martin van Bruinessen, NU: Tradisi, Relasi-relasi Kuasa, Pencarian Wacana Baru (Yogyakarta: LKiS, 1999).

${ }^{8}$ Robin Bush, Nahdlatul Ulama and the Struggle for Power within Islam and Politics in Indonesia (Singapore: ISEAS, 2009), h. 27-29.

${ }^{9}$ Ibid.

${ }^{10}$ Ibid.

${ }^{11}$ Said Aqil Siradj, Ahlussunnah wal Jama'ah dalam Lintasan Sejarah (Yogyakarta: LKPSM, 1997), h. 15.

${ }^{12}$ Ibid.

${ }^{13}$ Ronald Alan Lukens-Bull, Jihad Pesantren di Mata Antropolog Amerika (Yogyakarta: Gama Media, 2004), h. 109.

${ }^{14}$ Mohamad Kholil, "Menggagas Pesantren sebagai Pusat Peradaban Muslim di Indonesia," dalam Media Akademika, Vol. 26, No. 3, Juli 2011, h. 4.

${ }^{15}$ Sa'di Abu Jaib, Al-Qâmus al-Fiqh Lughatan wa Isthilahatan (Damaskus: Dâr al-Fikr, 1988), h. 29.

${ }^{16}$ Muhammad Amin Suma, "Kelompok dan Gerakan," dalam Taufik Abdullah (ed.), Ensiklopedi Tematis Dunia Islam (Jakarta: Ichtiar Baru van Hoeve, t.t.), h. 367.

${ }^{17}$ Busyairi Harits, Islam NU: Mengawal Tradisi Sunni Indonesia (Surabaya: Khalista, 2010), h. 17. 
${ }^{18}$ Ibid.

${ }^{19}$ Ibid., h. 358; Departemen Agama RI, Ensiklopedi Islam di Indonesia (Jakarta: Departemen Agama RI., 1993), h. 76.

${ }^{20}$ Jalâl al-Dîn al-Suyuthi, Al-Dur al-Mantsûr, Juz II (Beirut: Dâr al-Fikr, 1993), h. 291.

${ }^{21}$ Ibid.

${ }^{22}$ Asep Saifuddin Chalim, Membumikan Aswaja (Surabaya: Khalista, 2012), h. 23

${ }^{23}$ Mamat S. Burhanudin, "Ahl al-Sunnah wa al-Jama'ah dan Dakwah Islam di Indonesia,” dalam Jurnal Bimas Islam, 2008, h. 180.

${ }^{24}$ Ibid.

${ }^{25}$ Ibid.

${ }^{26}$ Ibid.

${ }^{27}$ Ibid.

${ }^{28}$ Ibid.

${ }^{29}$ Ibid.

${ }^{30}$ Ibid.

${ }^{31}$ Harits, Islam NU, h. 24.

${ }^{32}$ Siradj, Ahlussunnah wal Jama’ah, h. 20.

${ }^{33}$ Ibid.

${ }^{34}$ Ibid.

${ }^{35}$ Ibid.

${ }^{36}$ Hasyim Muzadi, Nahdlatul Ulama di Tengah Agenda Persoalan Bangsa (Jakarta: Logos Wacana Ilmu, 1999), h. 113-114.

${ }^{37}$ Ibid.

${ }^{38}$ Ibid.

${ }^{39}$ Ibid.

${ }^{40}$ Ibid. h. 116.

${ }^{41}$ Ibid., h. 118.

${ }^{42}$ Jujun S. Suriasumantri, Filsafat Ilmu (Jakarta: Pustaka Sinar Harapan, 2003), h. 63. ${ }^{43}$ Jalaluddin, Filsafat Pendidikan Islam (Jakarta: Kalam Mulia, 2012), h. 123.

${ }^{44}$ Mujamil Qomar, Pesantren dari Transformasi Metodologi Menuju Demokratisasi Institusi (Jakarta: Erlangga, t.t.), h. 74.

${ }^{45}$ Abdurrahman Mas'ud, Dari Haramain ke Nusantara: Jejak Intelektual Arsitek Pesantren (Indonesia: Kencana, 2006), h. 263.

${ }^{46} \mathrm{Ja}$ 'far, "Tarekat dan Gerakan Sosial Keagamaan Shaykh Hasan Maksum," dalam Teosofi: Jurnal Tasawuf dan Pemikiran Islam, Vol. 5, No. 2, 2015.

${ }^{47} \mathrm{Al}$ Washliyah merupakan organisasi Islam yang lahir di Medan, Sumatera Timur (sekarang Sumatera Utara), 30 Nopember 1930. Paham keagamaan organisasi ini bisa dikatakan sama dengan NU. Lihat kajian tentang paham organisasi ini dalam 
Ja'far, "Peran Al Jam'iyatul Washliyah dalam Merevitalisasi Madhhab Shafi'i di Era Kontemporer," dalam Justicia Islamica: Jurnal Kajian Hukum dan Sosial, Vol. 13, No. 1, 2016.

${ }^{48}$ Tentang sejarah NU di Sumatera Utara lihat kajian Abbas Pulungan, "Nahdlatul Ulama di Luar Jawa: Perkembangan di Tanah Mandailing," dalam Journal of Contemporary Islam and Muslim Societies, Vol. 2, No. 1, 2018.

${ }^{49}$ Profil Pondok Pesantren Musthafawiyah Purba Baru Kabupaten Mandailing Natal (Purba Baru: Pesantren Musthafawiyah, 2012), h. 1.

${ }^{50}$ Ibid., h. 3.

${ }^{51}$ Muhammad Bahri Ghazali membagi pesantren kepada tiga kategori. Pertama, pesantren tradisional, yaitu pesantren yang masih mempertahankan bentuk asalnya dengan merujuk pada kitab-kitab yang ditulis oleh ulama-ulama abad ke-15, dan sistem pembelajarannya menerapkan sistem halaqah yang diadakan di masjid atau surau serta kurikulumnya sepenuhnya bergantung kepada kepakaran kiai. Kedua, pesantren modern yang telah meninggalkan sistem pembelajaran tradisional. Pesantren ini telah menggunakan sistem dan kurikulum madrasah atau sekolah. Perbedaannya terletak pada penekanannya pada pendidikan agama dan bahasa Arab. Ketiga, pesantren komprehensif yang mengembangkan sistem pesantren tradisional dan modern, kemudian menambah pendidikan keterampilan dan kemasyarakatan serta berperan aktif di tengah-tengah masyarakat. Muhammad Bahri Ghazali, Pendidikan Pesantren Berwawasan Lingkungan: Kasus Pondok Pesantren An-Nuqayah Guluk-Guluk Sumenep Madura (Jakarta: Pedoman Ilmu, 2001), h. 14-15.

${ }^{52} \mathrm{Al}$ Rasyidin telah mengkaji pembelajaran kitab kuning di Pesantren Musthafawiyah, lihat dalam Al Rasyidin, "Pembelajaran Kitab Kuning di Pesantren Musthafawiyah, Mandailing Natal," dalam Journal of Contemporary Islam and Muslim Societies, Vol. 1, No. 1, 2017.

${ }^{53}$ Profil Pondok Pesantren Musthafawiyah, h. 2.

${ }^{54}$ Pesantren ini mengembangkan paham Islam moderat, dan menolak radikalisme. Dari kurikulum pesantren dipahami bahwa karya-karya yang dikaji oleh para santri adalah karya ulama-ulama mazhab Sunni klasik. Karya-karya ideolog radikal seperti karya Sayyid Quthb tidak beredar di pesantren ini. Tentang paham Sayyid Quthb lihat Mhd. Syahnan, "Islam as a System: A Critical Analysis of Sayyid Quthb's Principle Thought," in Analytica Islamica, Vol. 4 No. 1, May 2002; Mhd. Syahnan, Contemporary Islamic Legal Discourse: A Study of Sayyid Quthb's Fi Zhilal al-Qur'an (Medan: IAIN Press, 2010).

${ }^{55}$ Salamuddin, "Corak Teologi Syekh Musthafa Husein” (Disertasi: Pascasarjana IAIN Sumatera Utara, 2013), h. 172.

${ }^{56}$ Ibid.

${ }^{57}$ Ibid., h. 15.

${ }^{58}$ Ibid., h. 14.

${ }^{59}$ Ibid. 
VOL. 3 NO. 1 JANUARI-JUNI 2019

${ }^{60}$ Salamuddin, "Corak Teologi Syekh Musthafa Husein,” h. 126.

${ }^{61} Y u s f a r$ Lubis, Syeikh Musthafa Husein Purba Baru 1886-1955 (Bandung: t.p., 1992), h. 6.

${ }^{62}$ Salamuddin, "Corak Teologi Syekh Musthafa Husein,” h. 128 